\title{
PENERAPAN PEMBELAJARAN DALAM JARINGAN (DARING) PADA SEKOLAH DASAR DI SDN 3 BULUSAN KARANGDOWO KLATEN
}

\author{
Putra Pamungkas \\ Magister Pendidikan Dasar Sekolah Pascasarjana Universitas Muhammadiyah Surakarta
}

\begin{abstract}
ABSTRAK
Penelitian ini bertujuan untuk mengetahui bagaimana penerapan pembelajaran dalam jaringan (daring) pada iswa SDN 3 Bulusan sebagai layanan pendidikan dimasa tanggap darurat covid-19. Persoalan yang akan dijawab dalam penelitian ini adalah bagaimana penerapan dan tahapan pembelajaran dalam jaringan selama pandemi Covid-19 di SDN 3 bulusan. Subjek penelitian ini adalah Kepala sekolah. Data primer diperoleh melalui wawancara yang mendalam dengan subjek penelitian yang dilanjutkan dengan observasi dan dokumentasi sebagai proses awal analisis. Selanjutnya, dianalisis dengan mereduksi dan mengklsifikasikan data. Setiap analisis dinarasikan secara deskriptif dan disimpulkan sesuai dengan pertanyaan rumusan masalahnya. Berdasarkan hasil identifikasi, penerapan pembelajaran dalam jaringan selama pandemi Covid-19 di SDN 3 Bulusan dilakukan melaui tahapan tujuan, perencanaan, materi, pelaksanaan, dan evaluasi. Pembelajaran dalam jaringan menggunakan aplikasi WhatsApp yang tergabung dalam WhatsApp Group kelas A. Pelaksanaan pembelajaran daring yang dilaksanakan meliputi kegiatan pembukaan, kegiatan inti, teknik tampilan dan sharing ilmu. Dan yang terakhir tahapan evaluasi pembelajaran daring yang berisi penilaian terhadap hasil kegiatan anak yang dikirim melalui video, foto, dan voicenote dan digunakan sebagai dasar penilaian harian, mingguan, bulanan, dan akhir semester.
\end{abstract}

Kata kunci: Pembelajaran Daring, siswa sekolah dasar, Virus Covid-19

\section{ABSTRACT}

This study aims to find out how to apply online learning to SDN 3 Bulusan students as an educational service during the COVID-19 emergency response. The question that will be answered in this research is how are the implementation and stages of online learning during the Covid-19 pandemic at 3 Bulusan? The subject of this research is the principal of the school. Primary data were obtained through in-depth interviews with research subjects followed by observation and documentation as the initial process of analysis. Furthermore, it is analyzed by reducing and classifying the data. Each analysis is narrated descriptively and concluded according to the question formulation of the problem. Based on the identification results, the application of online learning during the Covid-19 pandemic at SDN 3 Bulusan was carried out through the stages of objectives, planning, materials, implementation, and evaluation. Learning on the network uses the WhatsApp application which is part of the WhatsApp Group class A. The online learning implementation includes opening activities, core activities, display techniques and knowledge sharing. And the last stage is the online learning evaluation stage which contains an assessment of the results of children's activities that are sent via video, photos, and voicenotes and are used as the basis for daily, weekly, monthly, and end-of-semester assessments.

Keywords: Online Learning, elementary school students, Covid-19

\section{PENDAHULUAN}

Era revolusi industri 4.0 menjadi isu akhir-akhir ini, bahkan menjadi isu Internasional. Era dimana keterampilan dan kepemimpinan seseorang menjadi kemampuan untuk bertahan dalam Era Transformasi Teknologi yang begitu cepat. Era yang mempengaruhi seluruh sudut kehidupan termasuk pendidikan. Kemajuan pendidikan menjadi tolak ukur atau ujung tombak kemajuan bangsa, karena lewat pendidikan kita dapat meningkatkan kemampuan sumber daya manusia.

Dunia pendidikan harus senantiasa menyesuaikan perkembangan teknologi terhadap usaha dalam meningkatkan mutu 


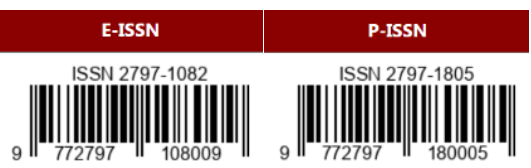

Volume 2 Nomor 1 (Desember 2021 - Februari 2022)

pendidikan, terutama penyesuaian penggunaan teknologi informasi dan komunikasi bagi dunia pendidikan khususnya dalam proses pembelajaran. Implementasi pemanfaatan teknologi informasi dan komunikasi dalam dunia pendidikan salah satunya dapat diwujudkan melalui Ipembelajaran dalam jaringan (daring). Melaui pembelajaran daring tidak mengharuskan guru dan peserta didik saling bertatap muka.

Dewasa ini ancaman wabah virus Corona tengah dihadapi bangsa Indonesia, permasalahan besar sedang dihadapi bangsa ini sebagai musibah nasional. Pandemi Corona virus atau biasa disebut dengan Covid19 merupakan virus yang pertama kali di temukan di Wuhan, Hubei, Cina mulai dari akhir tahun 2019 hingga saat ini tahun 2020 dan telah mewabah keseluruh penjuru dunia salah satunya di Indonesia. Syndrom pernapasan akut berat corona virus 2 ( Sars Cov 2). Sejak pertama kali ditemukan kasus positif Covid-19 pada senin 2 Maret 2020 yang langsung diumumkan oleh Presiden Joko Widodo. Berbagai kebijakan pemerintah diambil guna mencegah penyebaran mata rantai virus Corona atau Covid19. Berbagai kebijakan yang diambil antara lain seperti, anjuran sosial distancing, physical distancing, memakai masker, anjuran mencuci tangan dengan sabun, dan pola hidup sehat . Selain itu beberapa daerah mengambil kebijakan untuk meliburkan siswa dari tingkat TK sampai dengan Perguruan Tinggi guna mencegah penyebaran mata rantai virus Corona atau Covid-19. Kementrian Pendidikan dan kebudayaan (Kemendikbud) menerbitkan surat edaran Nomor 2 Tahun 2020 tentang pencegahan Covid-19 dilingkungan Kemendikbud dan Surat Edaran Nomor 3 Tahun 2020 tentang Pencegahan Covid-19
Pada satuan Pendidikan. Sedangkan pada tingkat Provinsi terdapat Surat Edaran Gubernur Jawa Tengah Nomor 440/0005942 Tentang Pencegahan Mata Rantai penyebaran Covid-19 maka kegiatan belajar mengajar mulai dari Pendidikan Anak Usia Dini hingga tingkat menengah atas diliburkan berlaku mulai dari tanggal 16 Maret sampai tanggal 29 Maret 2020 serta berubah sesuai dengan surat edaran terbaru.

Himbauan dari Pemerintah sesuai dengan protokol kesehatan tentang prosedur pencegahan penyebaran virus Covid-19 semua kegiatan sekolah harus ditiadakan dan anak-anak belajar dari rumah dan semua guru harus bekerja dari rumah. Dengan penerapan Work From Home (WFH) maka semua pihak harus mematuhi aturan yang diberikan. Dengan adanya himbauan ini , guru agar tetap memantau dan memberikan kegiatan kepada murid melalui pembelajaran dalam jaringan (daring). Sebuah tantangan baru bagi guru Pendidikan Anak Usia dini, yang selama ini belum pernah menggunakan penerapan pembelajaran dalan jaringan untuk kegiatan belajar mengajar. Dengan adanya WFH pada jenjang Pendidikan Anak Usia Dini diharapkan guru tetap bisa memantau perkembangan dan kegiatan anak di rumah , dan terus berinteraksi dengan anak dan orang tua.

Berdasarkan permasalahan diatas, maka setiap lembaga sekolah dituntut untuk berinovasi dalam kegiatan belajar mengajar tanpa melakukan tatap muka terhadap peserta didiknya. Penerapan teknologi dan komunikasi dalam dalam dunia pendidikan menjadi tidak asing lagi. Seperti yang telah disebutkan dalam kebijakan Ditjen SD Tahun 2019 mengenai pemanfaatan TI dalam pelaksanaan program SD Dikmas (MOOC, Anggun SD, Sahabat Keluarga). Selanjutnya 
yang menjadi pertanyaan, bagaimana metode pembelajaran dalam jaringan ini dapat dijalankan dalam jenjang pendidikan anak usia dini? Dan penerapan yang tepat yang harus guru SD terapkan dalam pembelajaran dalam jaringan. Karena situasi saat ini adalah suatu hal yang sangat fenomena yang sebelumnya tak pernah di bayangkan oleh dunia pendidikan yang harus berhenti total dalam kegiatan di sekolah.

Diberlakukannya libur sekolah dimasa pandemi virus Covid-19 mulai dari jenjang PAUD sampai Perguruan Tinggi maka setiap satuan pendidikan menerapkan pembelajaran jarak jauh demi menjaga dan memutus mata rantai penyebaran virus Covid-19. Semua kebiasaan berubah, begitu juga dengan pembelajaran-pembelajaran yang harus diterapkan dan tentunya harus tetap berjalan agar anak-anak sekolah tetap bisa belajar dan meningkatkan kemampuan akademiknya. Semua anak yang bersekolah punya hak yang sama untuk tetap menerima kegiatankegiatan pembelajaran yang diberikan oleh guru. Jenjang SD pun dimasa pandemi darurat virus Covid-19 memungkinkan sekali untuk tetap melaksanakan pembelajaran jarak jauh. Dengan adanya Teknologi yang semakin canggih, guru-guru yang pintar IT dan orang tua yang semakin mengikuti perkembangan IT. Anak-anak SD pun berhak untuk tetap mengikuti kegiatan pembelajaran di masa pademi virus Covid-19 karena mereka juga merupakan bagian dari wajib belajar, dan tentunya agar orang tua yang menyekolahkan anak-anaknya di lembaga SD tetap terpenuhi haknya. Bukan hal yang mudah, tetapi sangat mungkin sekali dilaksanakan pembelajaran untuk anak-anak SD Setelah adanya penerapan WFH dan dunia pendidikan diliburkan sejak tanggal 16 Maret 2020, pada awal April per tanggal 1 April 2020 peneliti melakukan study penelitian di kecamatan karangdowo terkait dengan penerapan pembelajaran yang diterapkan oleh sekolahsekolah dasar yang ada di kecamatan karangdowo selama sekolah diliburkan atau masa darurat Covid-19. Melaui wawancara lewat WA kepada beberapa kepala sekolah dan dewan guru serta orang tua SDN 3 Bulusan. Berdasarkan latar belakang masalah diatas maka rumusan masalah dalam penelitian ini adalah Bagaimana penerapan, tahapan dan pelaksanaan pembelajaran, serta kendala-kendala yang dihadapi dalam pembelajaran daring di SDN 3 Bulusan?

\section{TUJUAN}

Daring adalah istilah yang lekat dengan internet. Menurut KBBI, daring adalah akronim "dalam jaringan" yang berarti segala sesuatu dilakukan secara online. Daring adalah sejenis komunikasi yang bisa dilakukan dengan modal ponsel, laptop, komputer, tablet, dan internet. Praktiknya, daring digunakan sebagai pembelajaran virtual, sebutan populernya adalah pembelajaran daring. Pembelajaran ini diperantarai dengan berbagai macam aplikasi. Aplikasi yang biasanya digunakan adalah Zoom, Google Meet, WhatsApp, Line, Skype, dan lain sebagainya. Tujuan pembelajaran daring adalah memudahkan komunikasi penyampaian materi ajar dalam bidang pendidikan yang dilakukan jarak jauh. Tujuan pembelajaran daring umumnya diperuntukkan untuk metode ajar yang tidak tatap muka. Meski pembelajaran daring dilakukan secara virtual dan jarak jauh, penyusunan dari tujuan pembelajaran daring bukan malah menjadi semakin kabur, tetapi semakin penting. Tenaga pengajar tetap penting dalam melakukan penyusunan rangkaian pengembangan desain pembelajaran. Pada 
tahap ini, tenaga pengajar akan menentukan tujuan pembelajaran daring yang menjadi acuan untuk menentukan jenis materi pembelajaran, strategi pembelajaran, metode pembelajaran, dan media pembelajaran yang akan digunakan dalam proses pembelajaran. Tanpa tujuan pembelajaran daring yang jelas, pembelajaran daring justru akan menjadi kegiatan tanpa arah, tanpa fokus, dan menjadi tidak efektif. Menentukan tujuan pembelajaran daring akan sangat memudahkan guru memilih dan menyusun bahan ajar. Tujuan pembelajaran daring pasti memudahkan guru menentukan kegiatan belajar dan media yang hendak digunakan. Satu hal yang pasti, tujuan pembelajaran daring akan memudahkan guru mengadakan adanya penilaian meski pembelajaran dilakukan jarak jauh. Tujuan pembelajaran daring pun akan sangat memudahkan kegiatan belajar yang membuat siswa lebih mandiri

Begitu pula halnya di SDN 3 Bulusan dengan adanya penerapan pembelajaran daring maka siswa siswi SDN 3 Bulusan bisa belajar sesuai jadwal yang sudah ditentukan oleh sekolah walaupun belajarnya tidak secara tatap muka. Dengan pembelajaran daring siswa siswi bisa belajar dengan giat dan gurunya juga bisa mengajar dengan baik.

\section{METODE}

Pendekatan peneliti dalam penelitian ini adalah pendekatan deskriptif. Pendekatan deskriptif merupakan pendekatan dalam membuat sebuah gambaran terkait suatu kejadian. Jenis penelitian yang digunakan dalam penelitian ini menggunakan penelitian kualitatif. Penelitian kualitatif digunakan untuk mendeskripsikan atau menggambarkan fenomena, peristiwa, aktifitas sosial, sikap, kepercayaan maupun pemikiran orang secara individu maupun secara kelompok. (Nana
Syaodih, 2010:9). Kegiatan penelitian ini, dilakukan agar peneliti dapat memotret apa yang terjadi pada diri objek atau wilayah yang diteliti kemudian memaparkan apa yang terjadi dalam bentuk laporan secara lugas seperti apa adanya yaitu mendiskripsikan pelaksanaan, faktor pendukung, dan faktor penghambat dalam implementasi media pembelajaran daring pada pelajaran tematik siswa kelas 2 di SDN 3 Bulusan.

Peneliti mengumpulkan data-data hasil penelitian dari subyek yang diteliti tentang implementasi media pembelajaran daring pada pelajaran tematik siswa kelas $1 \mathrm{di}$ SDN 3 Bulusan. Dengan penjabaran proses penelitian yang diawali dari koordinasi dengan pihak sekolah baik kepala sekolah, guru, dan warga sekolah yang lain Dilanjutkan dengan melakukan tahap observasi pertama, observasi kedua, dan seterusnya kemudian diakhiri dengan pemeriksaan hasil penelitian.

Tempat dan Waktu Penelitian Penelitian dilakukan di Sekolah Dasar, Kecamatan karangdowo yang memiliki jumlah lembaga pendidikan terbanyak dibandingkan kecamatan lainnya. Adapun tempat penelitian dilaksanakan di SDN 2 Bulusan, SDN 1 Tulas dan SDN 3 Munggung. Waktu penelitian dilaksanakan pada Tahun Ajaran 2020/2021.

Sumber Data Sumber data dalam penelitian ini adalah data-data dari guru kelas 2 berupa media pembelajaran tematik dan hasil belajar siswa kelas 2, selebihnya adalah data tambahan seperti berupa rangkaian kata dan tindakan. Data dalam penelitian ini adalah keterangan atau bahan nyata yang dapat dijadikan sebagai bukti dan bahan dasar penelitian. Adapun sumber data yang akan digunakan oleh peneliti adalah: (1) Sumber data primer Sumber data primer pada 
penelitian ini adalah data yang di peroleh berupa media yang di dapat dari guru dan wawancara serta dukungan dengan gambargambar yang berkaitan dengan penelitian yang akan dilakukan di SDN 3 Bulusan; (2) Sumber data sekunder Sumber data sekunder yaitu sumber data yang mengandung informasi tambahan untuk melengkapi sumber data primer. Sumber data sekunder berasal dari kepala sekolah dan orang tua siswa kelas 2.

Instrumen Penelitian dari penelitian kualitatif adalah si peneliti itu sendiri. Peneliti kualitatif sebagai human instrument memiliki fungsi menetapkan fokus penelitian, memilih informan sebagai sumber data, melakukan pengumpulan data, menilai kualitas data, analisis data, menafsirkan data dan membuat kesimpulan dari temuannya (Sugiyono, 2017). Namun juga harus menggunakan pedoman dalam mengumpulkan sebuah data. Baik itu pedoman wawancara, pedoman observasi maupun pedoman studi dokumen yang membantu peneliti dalam mengumpukan data dilapangan. Oleh karena itu, peneliti menyusun kisi-kisi instrument untuk menjadi landasan dan membantu dalam pengumpulan data. Dalam Penelitian menggunakan tiga alat bantu (instrumen) dalam pengumpulan data, yaiut: (1) Lembar Wawancara sebagai alat pengumpulan data agar data yang dibutuhkan tidak melenceng dari tujuan penelitian yang telah ditetapkan; (2) Lembar Observasi untuk memperoleh data melalui proses mengamati situasi dan kondisi pada implementasi media pembelajaran daring pada pelajaran tematik siswa kelas 1 di SDN 3 Bulusan. Observasi dilakukan dengan kepala sekolah dan guru; (3) Dokumentasi sebagai alat bantu dalam kegiatan wawancara dan observasi agar pelaksanaan dapat berjalan dengan maksimal, tanpa terganggu harus melakukan pencatatan data-data pada kegiatan wawancara dan observasi, selain itu dokumentasi juga bermanfaat sebagai alat pendukung dalam kegiatan pengumpulan data. Dokumen yang digunakan untuk memperoleh data dalam penelitian ini berupa foto implementasi media pembelajaran daring di sekolah, foto guru mengajar online dan foto peserta didik dalam mengikuti pembelajaran daring.

Prosedur Penelitian Prosuder yang dilakukan pada penelitian ini ada tiga tahap, yaitu: tahap perencanaan penelitian, tahap pelaksanaan, dan tahap akhir

Analisis data yang dikemukakan oleh Sugiyono (2017:336) menyatakan bahwa analisis merupakan suatu pencarian serta penyusunan yang dilakukan secara sistematis terhadap data yang diperoleh. Pada penelitian ini dilakukan sejak pengumpul data. Data yang terkumpul di analisis berdasarkan hasil observasi proses implementasi media pembelajaran daring dan wawancara kepada kepala sekolah dan guru untuk menambah informasi.

Analisis data pada penelitian ini yaitu mengacuh pada analisis yang bersifat kualitatif seperti yang dikemukakan oleh Miles dan Huberman. Miles dan Huberman menyarankan menggunakan tiga tahap dalam melakukan analisis data diantaranya: data reduction, data dispay, conclusion dan data verifying (Sugiyono, 2017:337). Berikut model interakatif dalam analisis data.

\section{HASIL DAN PEMBAHASAN Deskripsi Data}

Hasil penelitian dan temuan penelitian yang telah dilakukan. Adapun paparan data penelitian berupa (1) data tentang proses penggunaan media daring di SDN 3 Bulusan, (2) data tentang kelebihan dan kekurangan media daring di SDN 3 Bulusan. 


\section{Analisis Data}

Pembelajaran yang efektif merupakan salah satu faktor penting dalam menunjang keberhasilan proses belajar peserta didik. Proses pembelajaran ini menjadi pusat perhatian guru dalam meningkatkan mutu pembelajaran peserta didik agar tercipta dengan baik. Pembelajaran akan mencapai hasil yang baik ketika teori dan praktik dapat berjalan dengan seimbang.

Pembelajaran Bahasa Indonesia menggunakan media daring yang dilakukan di SDN 3 Bulusan ini, proses belajarmengajar yang dilakukan untuk mencapai hasil pembelajaran tidak berjalan dengan efektif. Banyaknya materi yang ada dalam pembelajaran Bahasa Indonesia tidak dapat dijelaskan secara langsung secara lengkap. Selain itu, materi yang disampaikan secara daring juga belum tentu dapat dipahami semua peserta didik. Hasil pembelajaran yang dilakukan juga lebih mengarah pada penugasan yang diberikan guru. Tugas yang diberikan secara keseluruhan masih membuat peserta didik merasa kesulitan dalam memahami teori dan praktik.

Dalam penerapannya, antara teori dan praktik ini belum berjalan dengan seimbang. Guru belum menjelaskan teori dan praktik secara langsung. Hal ini juga dikarenakan terbatasnya penggunaan media daring dalam pembelajaran jarak jauh. Berbeda dengan pembelajaran tatap muka guru dapat menjelaskan teori dan praktik secara lebih detail.

Sebagai antisipasi dari hasil pembelajaran yang dilakukan, sehendaknya guru dapat menjelaskannya secara detail antara teori dan praktik. Maksudnya peserta didik bisa diberi teori dengan memberikan penjelasan dan tanya-jawab kemudian memberikan praktik. Sehingga peserta didik lebih mengerti tentang teori yang disampaikan dan mampu melakukan praktik dengan baik. Ketika pemahaman siswa terhadap teori baik maka praktinya juga akan menjadi baik.

Proses evaluasi yang digunakan guru dalam pembelajaran Bahasa Indonesia cukup beragam. Namun proses evaluasi yang digunakan masih berbasis penugasan melalui aplikasi Whatsapp yang secara umum banyak digunakan oleh peserta didik. Hal ini dapat dilihat dari ungkapan Bapak Diki sebagai berikut.

Evaluasi pembelajaran dalam proses belajar-mengajar sebagai tolak ukur dalam mencapai tingkat keberhasilan pembelajaran yang dilakukan. Secara umum evaluasi pembelajaran yang dilakukan guru dalam pembelajaran daring lebih mengarah pada penugasan melalui aplikasi Whatsapp. Hal ini dikarenakan aplikasi Whatsapp lebih mudah digunakan.

Berbeda dengan media daring seperti Zoom, Google Meet, atau aplikasi lainnya ini guru masih kesulitan dalam mengoperasikannya. Berbagai aplikasi yang cukup terbilang baru ini dalam penggunaannya juga tidak mudah. sehingga dalam mengoperasikannya guru dan peserta didik masih harus belajar agar proses belajar-mengajar yang dilakukan dapat berjalan lancar.

Meskipun evaluasi pembelajaran yang dilakukan ini hanya penugasan, namun evaluasi dalam pembelajaran Bahasa Indonesia ini sangat penting untuk dilakukan. Hal itu digunakan untuk mengetahui permasalahan yang ada ketika proses kegiatan belajar-mengajar berlangsung. Sehingga dengan adanya evaluasi pembelajaran ini guru bisa 
mengetahui sejauh mana keberhasilan peserta didik dalam melaksanakan proses pembelajaran. Kegiatan evaluasi pembelajaran ini dilakukan dengan harapan pembelajaran yang dilakukan akan menjadi lebih baik sesuai dengan tujuan yang diinginkan.

Dalam penerapannya, guru menyampaikan materi pembelajarandan peserta didik membaca materi yang disampaikan guru di grup Whatsapp. Melalui aplikasi tersebut peserta didik juga dapat bertanya kepada guru secara langsung terkait materi yang belum dipahami. Selain itu, kegiatan pembelajaran yang dilakukan dalam setiap minggunya juga dilakukan secara bergantian. Jadi, proses pembelajaran yang dilakukan setiap minggunya akan tetap menarik dan peserta didik tidak akan merasa bosan meskipun pembelajaran dilakukan secara daring.

Selain Whatsapp dan Zoom yang digunakan dalam pembelajaran, aplikasi sevima juga digunakan dalam proses pembelajaran Bahasa Indonesia di SDN 3 Bulusan. Aplikasi Sevima yang digunakan dalam pembelajaran Bahasa Indonesia ini dalam penggunaannya hampir sama dengan whatsapp. Hanya saja untuk aplikasi Sevima penggunaannya lebih mengarah pada tugas yang disampaikan guru. Dalam aplikasi Sevima, guru hanya memberikan penugasan saja. Peserta didik diberi form tugas oleh guru dan peserta didik tinggal mengerjakan. Hal ini berbeda dengan penggunaan media Whatsapp yang lebih mudah digunakan dalam pembelajaran. Melalui aplikasi Whatsapp, guru bisa langsung mengirim materi melalui grup kelas yang sudah tersedia. Selain itu proses melalui aplikasi Whatsapp juga dilakukan dengan tanya jawab, kuis, maupun diskusi.

\section{Kelebihan dan Kekurangan Media Daring}

Berdasarkan wawancara yang telah dilakukan di SDN 3 Bulusan ditemukan bahwa dalam penerapan media daring dalam pembelajaran Bahasa Indonesia terdapat kelebihan dan kekurangan. Adapun kelebihan dan kekurangan yang ditemukan adalah sebagai berikut.

\section{Kelebihan Media Daring}

Penerapan media daring memiliki kelebihan sebagaimana penjelasan berikut.

a) Mudah Diakses

Sistem pembelajaran yang awal mulanya dilakukan secara tatap muka kini sudah beralih dengan sistem pembelajaran daring. Proses pembelajaran daring ini dapat terlaksana dengan baik ketika sarana dan prasarana terpenuhi. Penggunaan media daring yang digunakan dalam proses pembelajaran harus mudah diakses agar pembelajaran yang dilakukan dapat berjalan dengan baik. Dengan adanya teknologi informasi yang sudah tersambung dengan jaringan internet ini pengguna dapat mengakses kebutuhan yang diinginkan dengan mudah. Berbagai platform yang tersedia dalam media daring kini juga mendukung terlaksananya proses pembelajaran. Jadi, kunci dalam suatu pembelajaran daring ini adalah media yang digunakan mudah diakses oleh siswa.

b) Efisien Waktu dan Tempat

Proses pembelajaran yang dilakukan secara daring cukup efisien dalam hal waktu dan tempat. Hal ini terlihat dari guru dan diswa yang melakukan proses pembelajaran dari rumah.

c) Fleksibel 
Dalam proses pembelajaran, peran media daring sangat penting untuk membantu memudahkan proses belajar peserta didik pada masa pandemi Covid19. Penggunaan media daring dalam pembelajaran jarak jauh ini cukup fleksibel untuk diterapkan. Hal ini terlihat dari penjelasan Bapak Diky sebagai berikut.

\section{Kekurangan Media Daring}

Penerapan media daring memiliki kekurangan sebagaimana penjelasan berikut:

a) Keterbatasan Sinyal dan Biaya untuk Internet

Penggunaan media daring sangat membutuhkan signal dan kuota paketan yang cukup memadai. Signal dan kuota paket sangat berkontribusi dalam membantu proses pembelajaran dalam dunia pendidikan. Namun, terbatasnya sinyal dan paket data ini menjadi kendala tersendiri bagi guru dan peserta didik dalam proses pembelajaran daring. Sehingga kegiatan belajarmengajar yang dilakukan dapat terhambat dan penggunaan media daring ini menjadi tidak efektif.

b) Pengawasan Belajar yang Tidak Maksimal

Guru memiliki persepsi bahwa dalam mengawasi peserta didik lebih mudah dilakukan dengan melakukan pembelajaran tatap muka. Berbeda dengan pembelajaran yang dilakukan secara daring guru tidak bisa selalu mengawasi siswa dalam belajar karena guru dan siswa tidak berada di tempat yang sama. Oleh karena itu, dalam pembelajaran daring ini orang tua sangat berperan untuk mengawasi siswa belajar di rumah. Dalam hal ini, salah satu upaya untuk mengoptimalkan proses pembelajaran yang baik, guru harus melakukan pembinaan yang terarah terhadap pelaksanaan pembelajaran siswa. Guru harus selalu memantau pembelajaran siswa secara daring dan memastikan siswa tetap belajar dari rumah. Hal ini sebagai dilakukan agar pembelajaran daring tetap berjalan dengan efektif dan inovatif.

c) Perbedaan Pemahaman terhadap Materi Media daring dalam proses pembelajaran yang dilakukan ini sebagai sarana pembelajaran yang dirasa cukup membantu. Denganmenggunakan media daring tentunya guru harus lebih ekstra memperhatikan masing-masing siswa. Setiap individu pasti memiliki keunikan sendiri terhadap kemampuan dalam belajar. Kemampuan individu dalam memahami suatu materi tentunya tidak sama, ada yang dengan mudah memahami dan ada juga yang lambat dalam memahami suatu materi. Oleh karena itu perlu adanya bimbingan secara bertahap dalam belajar. Apalagi pada masa pandemi ini proses pembelajaran dilakukan secara daring. Tentunya juga terdapat materi yang harus dijelaskan secara detail. Namun, karena akses media daring juga terbatas jadinya ketika proses pembelajaran dijelaskan secara detail media daring kurang efisien untuk diterapkan.

\section{PENUTUP \\ Kesimpulan}

Berdasarkan uraian di atas, maka penulis dapat mengambil kesimpulan 
mengenai penerapan pembelajaran dalam jaringan (daring) pada anak usia dini selama pandemi virus Covid-19 di SDN 3 Bulusan dilakukan melalui tahapan perumusan tujuan pembelajaran yaitu memberikan hak belajar kepada peserta didik selama pandemi Covid19 untuk belajar dari rumah, memantau perfoma peserta didik secara kontinue, memberikan kegiatan pemebelajaran yang lebih fleksible kepada peserta didik, dan memfasilitasi orang tua untuk sharing ilmu teradap perkembangan anak. Perencanaan pembelajaran daring yang berisi dengan persiapan pembelajaran yang meliputi persiapan, pemberitahuan, mengunduh Aplikasi WA dan kesepakatan guru dan orang tua. Materi pembelajaran daring yang berisi tentang Pengembangan Karakter,. Pelaksanaan pembelajaran daring yang meliputi kegiatan pembukaan, kegiatan inti, teknik tampilan dan sharing ilmu. Dan yang terakhir tahapan evaluasi pembelajaran daring yang berisi penilaian terhadap hasil kegiatan anak yang dikirim melalui video, foto, dan voicenote dan digunakan sebagai dasar penilaian harian, mingguan, bulanan, dan akhir semester.

Kendala-kendala yang dihadapi dalam penerapan pembalajaran daring di SDN 3 Bulusan adalah keterbatasan orang tua dalam kepemilikan hp android, pengetahuan orang tua dengan teknologi informasi, jaringan sinyal yang susah, dan keaktifan orang tua dalam peran sertanya mendampingi anak dalam belajar. Pembelajaran daring sebagai upaya dalam pemenuhan hak belajar anak dan orang tua di masa pandemi virus Covid19 yang sampai saat ini belum selesai

\section{Saran}

Berdasarkan hasil penelitian pembelajaran dalam jaringan (daring), ada beberapa saran yang perlu penulis sampaikan kepada beberapa pihak, yaitu:

1. Guru Guru harus memiliki persiapan yang jelas mengenai materi yang akan dijadikan bahan pembelajaran kepada orang tua sehingga orang tua bisa menerapkan dan tidak dibingungkan dengan kegiatan bermain. Guru harus lebih memperhatikan kondisi dan situasi lingkungan keluarga peserta didik dan mengambil jalan tengah. Guru selalu mengedukasi orang tua tentang pembelajaran anak SD adalah belajar sambil bermain, maka guru harus aktif dalam berkomunikasi dengan orang tua tentang pendampingan anak dalam setiap kegiatan.

2. Orang tua Sebagai orang tua harus mampu berperan aktif dan terbuka melaporkan kepada guru mengenai informasi perkembangan anak selama di rumah. Orang tua harus melaporkan secara jujur melaporkan kepada guru dengan hasil belajar anak di rumah. Orang tua diharapkan dapat selalu memberikan edukasi kepada anak tentang masa darurat virus Covid-19 yang sedang mewabah. Meyakinkan anak tentang alasan anak tidak diperkenankan berangkat kesekolah dan belajar di rumah. Orang tua juga harus tetap semangat sebagai guru di rumah agar anak semakin semangat dalam melaksanakan kegiatan bermain di rumah.

\section{DAFTAR PUSTAKA}

Ary Purmadi, M. Samsul Hadi.2018 "Pengembangan Kelas Daring Dengan Penerapan Hybrid Learning Menggunakan Chamilo Pada Mata Kuliah Kewarganegaraan”. 
Disertasi. Fakultas Ilmu Pendidikan,IKIP Semarang.

Atmoko Nugroho.2017 "Pengembangan Model Pembelajaran Jarak Jauh Berbasis WEB". Skripsi. Fakultas Teknologi dan Komunikasi,Universitas Semarang.

Haris Hardiansyah, 2004 "Metode Penelitian Kualitatif: Untuk Ilmu-ilmu Sosial’. Jakarta: Salemba Humanika.

Mokhamad Iklil Mustofa, Muhammad Chodzirin, Lina Sayekti, 2019"Formulasi Model Perkuliahan Daring Sebagai Upaya Menekan Disparitas Kualitas Perguruan Tinggi”. Tesis. Universitas Negeri Walisongo Semarang.

Siti Aisyah,dkk,2010." Perkembangan dan Konsep Dasar Pengembangan Anak Usia Dini” . Jakarta: Penerbit Universitas Terbuka

Suharsini Arikunto. 2002 "Prosedur Penelitian Suatu Pendekatan Praktek”. Jakarta: Rienka Cipta

Sutrisno Hadi.2002." Metodologi Research 2”. Yogyakarta: Andi Ofset,

Syarifudin . 2017 "Pengembangan Sistem Pembelajaran Online Di SMK Ungaran " Universitas Negeri Semarang.

Undang-undang No. 20 Tahun 2003

"Tentang Sistem Pendidikan Nasional." Jakarta

Peraturan Menteri Pendidikan dan Kebudayaan Republik Indonesia Nomor 146 Tahun 2014 "tentang Kurikulum 2013 Pendidikan Anak Usia Dini." JakartaSurat Edaran Nomor 4 Tahun 2020 "tentang Pelaksanaan Kebijakan Pendidikan Dalam Masa Darurat Penyebaran
Coronavirus Disease (COVID-19)", Jakarta

Keputusan Direktur Jendral Pendidikan Islam Nomor 2791 Tahun 2020 "tentang Panduan Kurikulum Darurat Pada Madrasah.” Jakarta

Devellopmentaly Appropriate Practice in Early Childhood Programs Serving Children From Birth trough Age 8. National Association for the Education of Young Children. Wasington, DC:1992

Surat Edaran Kementerian Kesehatan SE HK.02.01/MENKES/202/2020

"tentang Protokol Isolasi Diri Sendiri Dalam Penanganan Corona Virus Disease (Covid-19)”. Jakarta

Fitri, Nur Lailatul. (2019). Pemanfaatan Grup Whatsapp Sebagai Media Informasi Proses Belajar Anak di KB Permata Bunda. Al Hikmah: Indonesian Journal of Early Childhood Islamic Education Vol, 3 (2), 2019, PP. 151-166.

Hayati, Miratul., Purnama, Sigit. (2019). Perencanaan Pembelajaran

Pendidikan Anak Usia Dini. Depok: PT Grafindo Persada.

Joenady, A. Muis. (2019). Konsep dan Strategi Pembelajaran di Era Revolusi Industri 4.0. Yogyakarta: Laksana.

Soegijopranata, Universitas Khatolik. (2020). 21 "Refleksi Pembelajaran Daring di Masa Pandemi”, Semarang: Universitas Soegijopranata.

Sujiono, Yuliani Nuraini. (2009). "Konsep Dasar Pendidikan Anak Usia Dini”. Jakarta: Universitas Terbuka.

Susilo, dkk. (2020). Corona Virus Disease 2019: Tinjauan Literatur Terkini. 
Jurnal Penyakit Dalam Indonesia

Vol. 7, No. 1.

(https://www.kemendikbub.co.id diakses

pada tanggal 15 April 2020)

(https://id.m.wikipedia.org) diunduh pada minggu 31 Mei 2020.

(https://codemi.co.id) diunduh pada minggu 31 Mei 2020.

(https://www.kemdikbud.co.id) diunduh pada 31 Mei 2020)

(https://amp-kompas-

com.cdn.ampproject.org) diunduh

pada Jumat, 27 Maret 2020.

(https://infeksiemerging.kemkes.go.id)

diunduh pada 27 Maret 2020. 